\title{
PENGARUH PSIKOEDUKASI MANAJEMEN BURNOUT TERHADAP STRATEGI KOPING PADA IBU ASUH SEBAGAI CAREGIVER Di SOS CHILDREN'S VIILAGES SEMARANG
}

\author{
Mulya Virgonita Iswindari Winta \\ Putri Marleny Puspitawati
}

\begin{abstract}
ABSTRAK
Penelitian ini bertujuan untuk mengetahui secara empiris pengaruh psikoedukasi manajemen burnout terhadap strategi koping pada ibu asuh sebagai caregiver pada SOS Children's Villages Semarang. Subjek penelitian berjumlah 25 orang. Profesi penolong atau profesi yang terkait bidang sosial sangat rentan mengalami burnout atau kejenuhan. Pekerja sosial seperti caregiver pun termasuk rentan mengalami kondisi mental tersebut. Adapun sumber burnout yang dialami oleh para caregiver seperti beban kerja yang terlalu berlebihan, tuntutan pekerjaan yang tinggi, harapan orang lain yang tidak realistis terhadap hasil kerja caregiver, dan lain-lain. Kejenuhan atau burnout dapat menyebabkan penurunan efektifitas kerja kinerja individu. Burnout atau kejenuhan yang merupakan sindrom psikologis terdiri tiga dimensi, yaitu kelelahan emosi, depersonalisasi, dan penurunan pencapaian prestasi. Diperlukan kemampuan untuk manajemen burnout agar caregiver dapat mengatasi burnout yang dialaminya, penanganan ini disebut strategi koping, sehingga dapat melakukan tugasnya sebagai ibu asuh dengan lebih efektif.

Dalam penelitian ini metode yang digunakan adalah metode ekspreimen, dengan disain penelitian pre-test post-test without control group dimana subjek penelitian diberi perlakuan berupa psikoedukasi untuk dilihat pengaruhnya terhadap strategi koping untuk mengatasi burnout dan diukur saat sebelum perlakuan dan sesudah perlakuan. Hasil penelitian menunjukkan bahwa 6,9\% strategi koping dalam mengatasi burnout dipengaruhi oleh psikoedukasi manajemen burnout, yang bermakna terdapat faktor-faktor lain yang mempengaruhi strategi koping pada ibu asuh sebagai caregiver di SOS Children Villages Semarang
\end{abstract}

Kata Kunci: startegi koping, psikoedukasi manajemen burnout, caregiver

\section{ABSTRACT}

This study aims to determine empirically the effect of psychoeducation burnout management to the coping strategies in the foster mother as a caregiver at the SOS Children's Villages Semarang. The subjects included 25 people. Auxiliary professions or professions related to the social field are very susceptible to burnout. Social workers such as caregivers also are prone to experience these mental conditions. The source of burnout experienced by the caregiver as excessive workload, high job demands, expectations of others that are not realistic about the work of the caregiver, and others. Burnout can lead to decreased effectiveness of individual performance. Burnout which is a psychological syndrome consisting of three dimensions, namely emotional exhaustion, depersonalization, and decreased achievement. Management capabilities needed for caregiver burnout in order to overcome burnout experienced, this treatment is called coping strategies, so it can do its job as a foster mother more effectively.

In this study, the method used is the method Experimental, with the design of the study pre -test post-test without control group where the study subjects were treated in the form of psychoeducation to see its influence on coping strategies to cope with burnout and measured the time before treatment and after treatment. The results showed that $6.9 \%$ in overcoming burnout coping strategies are influenced by management psychoeducation burnout, which means there are other factors that influence coping strategies on the foster mother as a caregiver in an SOS Children's Villages Semarang

Keywords: coping strategies, psychoeducation burnout management, caregiver 


\section{Pendahuluan}

Direktur Kesejahteraan Sosial Anak Kementerian Sosial Republik Indonesia menyatakan bahwa jumlah anak yang memiliki masalah sosial di Indonesia masih tinggi. Hasil penelitian yang dilakukan oleh Setuningsih (2014) tercatat sebanyak 5,4 juta anak terlantar di Indonesia. Anak terlantar yang baru bisa tertangani oleh Kementerian Sosial sejumlah 200.000 anak saja. Kemungkinan meningkatnya jumlah anak-anak terlantar dari tahun ke tahun, menuntut perhatian, penanganan khusus, dan kerjasama dari berbagai pihak, baik dari instansi pemerintah maupun swasta seperti Lembaga Swadaya Masyarakat (LSM) pemerhati anak lainnya, dengan harapan dapat memberikan pelayanan terbaik bagi kesejahteraan anak.

Keluarga dan rumah merupakan kebutuhan mendasar yang paling penting bagi tumbuh kembang anak. Lingkungan keluarga dan rumah yang sehat dapat menciptakan anak-anak yang sehat jasmani dan rohani. Menurut United Nations Convention On the Rights Of The Child (Konvensi PBB tentang Hak-Hak Anak) pasal 20 dan 21, anak memiliki hak untuk mendapatkan pengasuhan dan bantuan khusus, apabila mereka tidak tinggal dengan orang tua, dan anak memiliki hak untuk diasuh dan dilindungi ketika mereka diadopsi atau berada di keluarga asuh. Rumah kedua atau alternatif tempat tinggal yang biasa dikenal sebagai panti asuhan atau panti sosial, dapat di kelola oleh pemerintah atau organisasi non-pemerintah.

Panti sosial yang dikelola oleh salah satu organisasi internasional di Semarang adalah SOS Children's Villages yang memiliki cabang di beberapa kota di Indonesia dan negara-negara lain. SOS Children's Villages adalah Non Goverment Organizational (NGO) terbesar di dunia yang bergerak di bidang pengasuhan anak, didirikan pada tahun 1949 di Austria. SOS Children's Villages bekerja di 133 negara di dunia, termasuk di Indonesia. SOS memberikan rumah dan keluarga alternatif kepada mereka yang membutuhkan serta memastikan setiap seorang anak mendapat haknya. Di SOS Children's Villages tersebut terdapat beberapa pekerja sosial yang mengurusi anak-anak tersebut.
Pekerja sosial adalah suatu profesi yang bertugas sebagai agen pedorong perubahan sosial. Mereka berperan penting dalam memberikan pemecahan masalah yang terkait dengan relasi kemanusiaan, pemberdayaan, dan mendukung kebebasan masyarakat dalam meningkatkan kesejahteraannya. Pekerja sosial sebagai agen pendorong perubahan sosial mengandung arti bahwa mereka berusaha membantu individu, kelompok, bahkan masyarakat dapat berfungsi sosial secara baik dan efektif, terkait dengan hasil interaksi orang dengan lingkungan sosialnya (Rohman, 2014). Pekerja sosial dalam penelitian ini adalah pekerja sosial yang bertugas sebagai caregiver (ibu asuh) anakanak yang bertempat tinggal di SOS Children's Villages.

Aktivitas caregiver di SOS Children's Villages_cabang Semarang dalam kehidupan sehari-harinya terlibat langsung dengan individu-individu lain baik dengan rekan sejawat dan anak-anak asuh. Kontak langsung tersebut dalam bentuk pertemuan rapat secara periodik sesama rekan sejawat dan atasan dan program harian-mingguan-bulanan-tahunan dengan anak-anak asuh. Selain itu, caregiver juga melakukan intervensi dini jika terjadi suatu kasus, seperti mencari anak yang melarikan diri, mengantar jemput anak asuh sekolah, membantu perawatan diri para anak asuh, dan lain-lain.

Kelebihan beban kerja dan tuntutan pekerjaan yang tinggi pada para pekerja sosial dalam kehidupan sehari-harinya dapat menyebabkan burnout atau jenuh (Schaufeli dan Bakker, 2004; Zagladi, 2004 dalam Tamaela, 2011). Menurut Schaufely dan Bunnk (1996) menjelaskan bahwa $43 \%$ burnout terjadi pada profesi bidang kesehatan dan pekerja sosial (Firdaus, 2006). Sejalan dengan pendapat Maslach yaitu profesi penolong seperti dokter, perawat, dan pekerja sosial adalah profesi yang cenderung mengalami burnout atau jenuh (Harris at al, 2006 dalam Tamaela, 2011).

Berdasarkan studi penjajagan terhadap beberapa caregiver di SOS Children's Villages di Indonesia cabang Semarang yang dilakukan pada bulan April - Mei 2015, caregiver mengalami kehilangan minat untuk melakukan aktivitas menyenangkan lainnya (hanya melakukan rutinitas sehari-hari saja) ter- 
kadang mengalami kelelahan emosi dan fisik tanpa alasan yang jelas; penurunan kualitas tidur; terkadang merasa tidak berdaya; dan perubahan berat badan yang signifikan. Halhal yang dialami oleh beberapa caregiver di SOS Children's Villages di Indonesia cabang Semarang telah menunjukkan beberapa simptom dari burnout atau jenuh yang dialami oleh para caregiver.

Salah satu cara mereduksi intensi stres ke burnout adalah dengan strategi koping. Mekanisme koping adalah cara yang dilakukan individu dalam menyelesaikan masalah, menyesuaikan diri dengan perubahan serta respon terhadap situasi yang mengancam (Kelliat, 1999). Penelitian empiris menunjukkan bahwa koping yang berorientasi pada masalah berhubungan dengan peningkatan kepuasan kerja, penurunan kekhawatiran dan distres psikologis. Menurut Fortes-Ferreira et al. (2008) koping yang berorientasi pada emosi hasilnya tidak konsisten. Beberapa studi menemukan bahwa koping yang berorientasi pada emosi dapat membantu mengurangi gejala-gejala psikosomatis dan distres psikologis, sementara hasil penelitian lainnya melaporkan adanya peningkatan distres psikologis dan gejala psikosomatis.

Penelitian ini dilakukan dengan tujuan untuk mengetahui secara empiris pengaruh psikoedukasi manajemen burnout terhadap strategi koping pada ibu asuh sebagai caregiver di SOS Children's Villages.

\section{Kajian Pustaka}

Menurut Freudenberger

menyatakan bahwa burnout adalah reaksi negatif kondisi psikologis terhadap pekerjaan yang meliputi simptom kelelahan secara emosi dan fisik serta kehilangan motivasi. Maslach (1976) menjelaskan kesamaan burnout dengan multidimensional sindrom stres yang terdiri dari kelelahan emosi, persepsi dan perasaan negatif individu (depersonalisasi), dan penurunan profesionalitas dalam bekerja atau kompetensi (Hakanen \& Schaufeli, 2012).

Kebanyakan peneliti menyetujui bahwa jika individu yang bekerja mengalami burnout memiliki karakteristik kelelahan pada level tinggi dan sikap serta perilaku negatif terhadap apa yang mereka kerjakan (Maslach, Schaufeli \& Leiter, 2001 dalam Demerouti, Bakker \& Mostert, 2010).
Individu yang mengalami burnout atau kejenuhan akan mengalami beberapa gejala, antara lain: (a) Timbulnya kelelahan fisik dengan ditandai merasa terkuras tenaganya secara berlebihan dan tanpa alasan yang jelas, mudah merasa sakit kepala, mudah lelah, mual, dan ada perubahan pola makan dan tidur. (b) Timbulnya kelelahan emosi seperti munculnya depresi, frustasi, merasa tertangkap dalam pekerjaan, merasa tidak berdaya, mudah tersinggung, dan apatis. (c) Timbulnya kelelahan mental seperti adanya sikap sinis terhadap orang lain, adanya prasangka negatif, dan memandang negatif diri sendiri dan pekerjaan. (d) Timbulnya perasaan tidak berdaya dalam mencapai sesuatu yang berarti dalam hidup dengan ditandai ketidakpuasan terhadap diri sendiri dengan pekerjaan dan kehidupannya (Leatz \& Stolar dalam As'ad \& Sutjipto, 2000)

Menurut Maslach dkk (2001), dua faktor yang mempengaruhi burnout adalah faktor situasional yang meliputi beban kerja berlebihan, minimnya fasilitas, dan kurangnya dukungan sosial serta faktor individual yang meliputi karakteristik kepribadian dan karakteristik demografi (usia, jenis kelamin) seperti rendahnya ketahanan mental, locus of control eksternal, strategi coping yang defensif atau menghindar, dan kepribadian tipe A (Widiastuti \& Astuti, 2008).

Caregiver adalah seseorang yang memberikan bantuan kepada orang yang mengalami ketidakmampuan dan memerlukan bantuan karena penyakit dan keterbatasannya (Sukmarini, 2009 dalam Sarwendah, 2013). Para caregiver di SOS Children's Villages Indonesia cabang Semarang merupakan caregiver formal dengan dibayar secara profesional. Caregiver di SOS memiliki 2 bagian tugas yaitu Pertama, sebagai pemberi pelayanan dan perawatan kehidupan seharihari, memberikan edukasi, dan advokasi hakhak anak pada para anak asuh. Kedua, mengasuh mereka dengan penuh penerimaan dan penghargaan sehingga mereka nyaman berada di SOS.

Burnout pada caregiver adalah kondisi mental kelelahan pada fisik, emosi, dan mental yang diikuti perubahan perilaku dari perilaku positif atau kepedulian sampai ke perilaku negatif atau ketidakpedulian. Kejenuhan pada caregiver disebabkan karena 
caregiver tidak mendapatkan bantuan yang dibutuhkan sebaliknya dituntut melakukan lebih di atas kemampuan.

Caregiver yang merasa jenuh akan mengalami kecemasan, depresi, stres, dan kelelahan (Serrano-Aguilar et al. 2006, Papastavrou et al. 2007, Molyneux et al. 2008 dalam Kim H, Chang, Rose, \& Kim S, 2011). Kejenuhan caregiver dapat menyebabkan munculnya perasaan bersalah terhadap orang yang mereka rawat, pada saat mereka meluangkan waktu untuk dirinya. Kejenuhan dapat juga berdampak pada penurunan produktivitas kerja, kedisiplinan, dan bereaksi negatif terhadap perubahan organisasi (Burke, Koyuncu \& Fiksenbaum, 2010).

Pengelolaan atau manajemen burnout perlu dilakukan agar pekerja sosial dapat melaksanakan tugasnya secara efektif. Pada kenyataannya tidak semua pekerja sosial paham tentang kondisi yang dialaminya. Mereka bisa merasakan yang dialami, tanpa tahu apa itu, penyebabnya dan penanganannya. Dengan memberikan pemahaman tentang kondisi yang dialami dan bagaimana cara mengatasinya, maka pekerja sosial akan dapat menyelesaikan masalahnya.

Psikoedukasi dikembangkan oleh Mottaghipoer dan Bickerton (2005), berupa kerangka kebutuhan pelayanan keluarga yang mengalami gangguan kesehatan mental yang disebut "Pyramid of Family Care". Piramid ini dikembangkan berdasarkan hirarki kebutuhan menurut Maslow, dimana tingkat dasar adalah connection and assessment, tingkat kedua: general education, tingkat ketiga: psychoeducation, tingkat keempat consultation dan tingkat kelima (tertinggi) adalah Family therapy. Psikoedukasi merupakan suatu tindakan yang diberikan kepada individu dan keluarga untuk memperkuat strategi koping atau suatu cara khusus dalam menangani kesulitan perubahan mental. Psikoedukasi adalah sebuah tindakan modalitas yang disampaikan oleh profesional yang mengintegrasikan dan mensinergikan antara psikoterapi dan intervensi edukasi (Lukens dan McFarlane, dalam Certwirght, 2007).

Psikoedukasi merupakan pengembangan dan pemberian informasi dalam bentuk pendidikan masyarakat mengenai informasi yang berkaitan dengan psikologi populer/ sederhana atau informasi dan yang mem- pengaruhi kesejahteraan psikososial masyarakat. Pemberian informasi ini bisa mempergunakan berbagai macam media dan pendekatan. Psikoedukasi bukan merupakan suatu pengobatan, namun hal ini dirancang untuk menjadi bagian dari rencana perawatan secara keseluruhan. Pada program psikoedukasi terdapat komponen latihan ketrampilan yang terdiri dari komunikasi, latihan menyelesaikan konflik, latihan asertif, latihan mengatasi perilaku dan mengatasi kecemasan. Lukens dan McFarlane (dalam Cartwright, 2007) mengutip beberapa hasil penelitian yang menunjukkan bahwa intervensi psikoedukasi dapat menurunkan gejala masalah kesehatan mental, khususnya dapat menurunkan kecemasan dan depresi.

Stone dan Neale (1994) mengatakan bahwa coping merupakan cara yang dilakukan individu, baik yang tampak atau tidak tampak untuk menghadapi situasi yang menimbulkan tekanan. Coping dipandang sebagai suatu proses dinamik dari suatu pola perilaku atau pikiran-pikiran seseorang yang secara sadar digunakan untuk mengatasi tuntutan-tuntutan dalam situasi yang menekan atau menegangkan. Smet (1994) mengatakan coping merupakan cara yang dilakukan seseorang untuk menghadapi situasi yang menekan. Pada saat ini, proses coping terhadap stres menjadi pedoman untuk mengerti reaksi seseorang terhadap stres itu sendiri

Menurut Lazarus dan Folkman (dalam Hapsari, dkk, 2002) menyatakan bahwa strategi coping yang merupakan respon individu terhadap tekanan yang dihadapi secara garis besar dibedakan atas dua fungsi utama yaitu: Problem Focused Coping (PFC) dan Emotional Focused Coping (EFC). PFC atau yang biasa disebut strategi menghadapi masalah yang berorientasi pada masalah merupakan usaha yang dilakukan oleh individu dengan cara menghadapi secara langsung sumber penyebab masalah. EFC atau yang biasa disebut strategi menghadapi masalah yang berorientasi pada emosi merupakan perilaku yang diarahkan pada usaha untuk menghadapi tekanan-tekanan emosi atau stress yang ditimbulkan oleh masalah yang dihadapi.

Hipotesis yang diajukan dalam penelitian ini adalah : Ada pengaruh Psikoedukasi manajemen burnout terhadap strategi koping 
pada ibu asuh sebagai caregiver pada SOS Children's Villages di Semarang

\section{Metode Penelitian}

Penelitian ini merupakan penelitian kuantitatif dengan desain quasi ekasperimen. Penelitian quasi eksperimen merupakan penelitian yang mengujicobakan suatu intervensi pada sekelompok subjek dengan atau tanpa kelompok pembanding, namun tidak dilakukan randomisasi untuk memasukkan subjek ke dalam kelompok perlakuan atau kelompok kontrol. Rancangan penelitian yang digunakan adalah pre-test and post-test without control, yaitu suatu rancangan yang melakukan perlakuan pada satu kelompok tanpa pembanding. Efektivitas perlakuan dinilai dengan cara membandingkan nilai pretest dan post-test.

Variabel dalam penelitian ini adalah Strategi Koping Burnout dan Psikoedukasi Manajemen Burnout.

Populasi dalam penelitian ini adalah ibu asuh yang menjadi caregiver pada SOS Children's Villages Semarang yang berjumlah 25 orang. Prosedur teknis yang dilakukan dalam penelitian ini antara lain : (a) Penjelasan tujuan penelitian, manfaat penelitian waktu penelitian serta meminta persetujuan responden. (b) Pelaksanaan kegiatan penelitian dengan pemberian intervensi psikoedukasi tentang burnout (sesi satu), yaitu memberikan segala informasi tentang burnout. Pada saat ini terjadi proses diskusi antara peneliti dan peserta. (c) Selanjutnya pada hari yang sama, responden diberikan intervensi tentang manajemen burnout dan latihan ketrampilan koping dalam menghadapi burnout. Pada bagian ini responden diberi simulasi tentang (1) managing negative emotion (Ball Bull), (2) deal with emotional burden (meditation) dan (3) daily selfcare-Exercise, Eat and Rest Right. (d) Penilaian Post-Test dilakukan setelah pelatihan psikoedukasi manajemen burnout dilakukan.

Analisis data pada penelitian ini menggunakan paired t-test Rumus paired t-test :

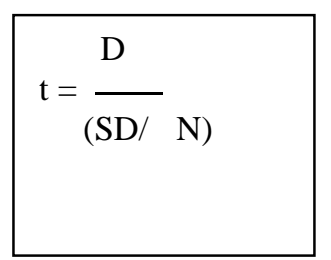

Keterangan rumus :

$\mathrm{t}$ : Nilai thitung

D : Rata-rata selisih pengukuran 1

SD : Standar deviasi selisih pengukuran $1 \& 2$

$\mathrm{N}$ : Jumah sample

\section{Hasil penelitian}

Hasil menunjukkan terdapat sumbangan psikoedukasi manajemen burnout terhadap kemampuan manajemen burnout sebesar $\mathrm{R}^{2}=$ $263^{2}$ atau sebesar $0,069(6,9 \%)$. Hal ini bermakna bahwa peningkatan kemampuan manajemen burnout pada ibu asuh sebagai caregiver sebesar $6,9 \%$ dipengaruhi oleh psikoedukasi manajemen burnout. Hal ini bermakna $93,1 \%$ disebabkan oleh faktor lain. Hasil uji $\mathrm{t}$ sebesar $=-12,680$ (lebih besar dari daripada 2,56) bermakna taraf perbedaan kemampuan manajemen burnout diterima pada taraf $99 \%$.

Hasil ini menunjukkan bahwa psikoedukasi tentang manajemen burnout dapat memberikan sumbangan terhadap strategi koping pada ibu asuh sebagai caregiver di SOS Children Villages Semarang, namun pengaruhnya kecil. Hal ini terkait dengan beberapa kondisi yang melingkupi kelemahan pada penelitian ini antara lain, pelatihan yang hanya diberikan sekali sehingga tidak menimbulkan daya ubah yang cukup kuat pada strategi koping yang dilakukan, media psikoedukasi yang hanya menggunakan ceramah dan diskusi, serta beberapa faktor yang tidak dikontrol yang diduga berpengaruh terhadap strategi koping antara lain tingkat pendidikan, kemampuan negosiasi dan kepribadian subjek penelitian

\section{Pembahasan}

Hasil pada penelitian ini menunjukkan psikoedukasi manajemen burnout memiliki pengaruh terhadap strategi koping burnout pada ibu asuh sebagai caregiver di SOS Children's Villages sebesar 6,9\%, yang bermakna 93,1\% strategi koping burnout dipengaruhi faktor-faktor lain selain psikoedukasi yang diberikan. Kecilnya pengaruh psikoedukasi manajemen burnout terhadap strategi koping diduga karena media yang diberikan pada sesi psikoedukasi hanya melalui media ceramah melalui power point 
tanpa didukung media seperti leaflet, buku saku ataupun materi tercetak lainnya, sehingga pemahaman mengenai manajemen burnout hanya terserap secara terbatas.

Beberapa faktor yang diduga berpengaruh terhadap strategi koping burnout adalah misalnya tingkat pendidikan, sebab sebagaimana dinyatakan oleh Lazarus dan Folkman (dalam Rustiana, 2003) coping terdiri atas strategi yang bersifat kognitif dan behavioral. Terdapat tahapan dimana individu berpikir dan mempertimbangkan beberapa alternatif pemecahan masalah yang tersedia, meminta pendapat orang lain, berhati-hati memutuskan masalah serta mengevaluasi strategi yang pernah dilakukan. Tingkat pendidikan subjek penelitian yang menjadi responden dalam penelitian ini tidak dikontrol sehingga dapat menimbulkan bias.

Kemampuan negosiasi merupakan salah satu faktor yang mempengaruhi strategi koping. Sebagaimana dinyatakan oleh Lazarus dan Folkman (dalam Rustiana, 2003) perlu suatu kemauan dan kemampuan untuk negosiasi seseorang kepada orang lain yang merupakan penyebab masalah untuk ikut menyelesaikan masalah. Kemampuan negosiasi tidak dikontrol dalam penelitian ini.

Karakteristik turut berpengaruh dalam strategi koping. Pada individu yang pesimis, strategi koping yang dilakukan menganggap tidak ada lagi yang dapat dilakukan dalam menghadapi tekanan dari luar, cenderung menyalahkan diri sendiri. Sementara individu dengan karakter optimis lebih percaya bahwa waktu akan menyelesaikan masalah dan keadaan akan membaik kembali. Lokus kendali juga berpengaruh terhadap strategi koping, individu dengan lokus kendali internal percaya bahwa harus bertindak sendiri dalam mengatasi masalah yang dihadapinya, sementara individu dengan lokus kendali eksternal cenderung mengharap orang lain akan membantu menyelesaikan masalahnya. Faktor-faktor inilah yang berpengaruh terhadap strategi koping burnout yang tidak dikendalikan dalam penelitian ini.

Psikoedukasi sendiri bertujuan untuk meningkatkan pencapaian pengetahuan, menambah wawasan ibu asuh sebagai caregiver dalam upaya melindungi diri dan keluarga yang diasuhnya untuk mengetahui gejala-gejala perilaku dan mendukung kekuatan keluarga, sehingga dapat menetapkan strategi koping dalam mengatasi burnout. Dalam psikoedukasi yang terdiri dari dua sesi, ibu asuh diajarkan mengenai cara mengidentifikasi burnout yang dialami, faktor penyebab dan dampak burnout bagi kesehatan fisik dan mental. Pada sesi kedua diajarkan tentang bagaimana melepaskan emosi-emosi negatif, dan menerima keadaan diri. Pada sesi kedua responden diajak melakukan meditasi untuk merenungkan diri dan perilaku diri.

\section{Daftar Pustaka}

As'ad, M \& Sutjipto. P. H. 2000. Hubungan Antara Beberapa Aspek Budaya Perusahaan Dengan Tingkat Burn-out Pada Karyawan bagian Publik. Jurnal Psikologi, 2, 101-110

Burke, R. J., Koyuncu, M., \& Fiksenbaum. 2010. Burnout, Work Satisfactions, and Psychological Well Being Among Nurse In Turkish Hospitals. Europe's Journal Of Psychology, 63-81.

Demerouti. E, Bakker. B. A, \& Mostert, K. 2010. Burnout and Work Engagement: A Through Investigation of the Independency of Both Constructs. Journal of Occupational Health Psychology, Vol 15, No. 3, 209-232.

Firdaus, U. 2006. Forum Guru, "Burnout". Bandung : Pikiran Rakyat. Diunduh pada tanggal 6 Februari 2015 dari www.pikiranrakyat.co.id

Hakanen, J. J \& Schaufeli, B, W. 2012. Do Burnout and Work Engagement Predict Depressive Symptoms and Life Satisfaction ? A Three Wave Seven Year Prospective Study. Journal of Affective Disorders , 141, 415-424.

Kim, H., Chang, M., Rose, K., \& Kim, S. 2011. Predictors of caregiver burden in caregiver of individuals with dementia. Journal of Advance Nursing, 846-855.

Low, S G., Cravens, W. D., Grant, K., Moncrief, C. W. 2001. Antecedents 
and Consequences Of Salespersons

Burnout. European Journal Of

Marketing, Vol 35, No 5/6, 587-611.

Moelong, L. J. 2000. Metodologi Penelitian Kualitatif. Bandung: Penerbit PT Remaja Rosdakarya.

Poerwandari, Kristi. 2005. Pendekatan Kualitatif untuk Penelitian Perilaku Manusia. Jakarta: Fakultas Psikologi Universitas Indonesia.

Rohma, F, A. 2014. Intervensi Mikro Pekerja Sosial Terhadap Anak Asuh di Panti Sosial Asuhan Anak (PSAA) Yogyakarta Unit Budhi Bakti Wonosari-Gunung Kidul. Skripsi. Perpustakaan UIN. Yogyakarta

Sarwendah, E. 2013. Hubungan Beban Kerja Dengan tingkat Stress Kerja Pada Pekerja Sosial Sebagai Caregiver Di Panti Sosial Tresna Werdha Budi Mulia DKI Jakarta 2013. Skripsi. Perpustakaan UIN. Jakarta
Setuningsih, N. 2014. 5,4 juta Anak Indonesia Terlantar. Diunduh pada tanggal 6 Februari 2015 dari www. sp.beritasatu.com/home

Tamaela, Y. E. 2011. Konsekuensi Konflik Peran, Kelebihan Beban Kerja dan Motivasi Intrinsik terhadap Burnout pada Dosen yang Merangkap Jabatan Struktural. Journal of Asset Vol. 3 No. 2, hal 111-122.

Widiastuti, Z. D \& Astuti, K. 2008. Jurnal Insight : Hubungan Antara Kepribadian Hardiness dengan Burnout Pada Guru Sekolah Dasar. Diunduh pada tanggal 6 Februari 2015 dari http://fpsi.mercubuanayogya.ac.id

www.huntsmancancer.org

www.senior-helpers.com

www.sos.or.id 